\section{Ved V., Nikolsky V., Okhtina D., Kiselev V.}

\title{
RESEARCH OF GAS CONTENT AND INTERFACIAL AREA IN THE DOWNFLOW PIPES OF A CIRCULATION APPARATUS WITH JET INJECTION GAS FILLING
}

\begin{abstract}
Об’єктом дослідження є апарат зі струменево-інжекиійним газонаповненням. Дослідження проводились на експериментальній установці на робочому середовищі вода-повітря. Досліджено розподіл бульбашок газової фази в залежності від робочих параметрів апарату. Визначено значення локального та загального газовмісту, а також питомої поверхні контакту фаз. Досліджено газовміст та поверхню контакту фаз в опускних трубах циркуляційного апарату зі струменево-інжекціцйним газонаповненням. Використання циркуляційних апаратів зі струменево-інжекційним газонаповненням є перспективним для проведення масообмінних та реакційно-масообмінних процесів. Завдяки використанню енергї рідини для газонаповнення реакційного простору, апарати мають переваги у порівнянні з ерліфтними та газліфтними апаратами, барботажними колонами при проведенні хемосорбційних процесів зі слаборозчинними газами. Експериментальні дослідження газовмісту та поверхні контакту фаз від режимно-технологічних та апаратурно-конструктивних параметрів дозволили визначити оптимальні режими роботи. За результатами досліджень встановлено, що діаметр бульбашок збільшується зі збільшенням числа обертів валу перемішуючого пристрою. Режим підвисання газової фази мав місце при числах оберту валу від 600 об/хв. до 750 об/хв. При збільшенні числа обертів збільшується протидія силі спливання бульбашок i режим підвисання переходить в режим циркулящї газорідинного потоку. Можливість керувати процесом газонасичення завдяки циркулящї рідини незалежно від навантаження по рідині апарату є однією з переваг розробленої конструкції. Встановлено, що загальний газовміст в опускних каналах змінювався від 0,07...0,10 до 0,1...0,18, що є характерним для газорідинних апаратів. Загальний газовміст в опускних каналах апарату знаходиться в діапазоні від 100 до $260 \mathrm{~m}^{2} / \mathrm{m}^{3}$ реакційного об'єму і є характерним для більшості газорідинних апаратів барботажного типу. Отримані результати досліджень режимів роботи апарату зі струменево-інжекційним газонаповненням в режимі підвішування газової фази можуть бути використаними для розрахунку коефіцієнту масопереносу.
\end{abstract}

ключові слова: струменево-інжекційний апарат, опускна течія, циркуляційний контур, газовміст, поверхня контакту фаз.

Received date: 04.06.2019

Accepted date: 26.06 .2019

Published date: 30.08 .2019
Copyright (C) 2019, Ved V., Nikolsky V., Okhtina O., Kiselev V. This is an open access article under the CC BY license (http://creativecommons.org/licenses/by/4.0)

\section{Introduction}

Prospects for the use of circulating devices with jet injection gas filling for mass transfer and reaction-mass transfer processes are highlighted in [1-3]. Due to the use of water energy for gas filling the reaction space, devices with jet injection gas filling have advantages compared to airlift, gas-lift and bubble devices in chemisorption processes with slightly soluble gases $[4,5]$. At the moment, devices with jet injection gas filling are widely used in the food industry [6] and in water treatment by ozonation [7].

Injection-jet apparatuses relate to gas-liquid apparatuses in which gas filling occurs due to the energy of a liquid [1]. Such devices can be divided into two groups. The first, in which gas saturation occurs due to the energy of the liquid jet, enters the free surface of the liquid. The second, in which gas saturation occurs due to the vortex funnel formed during fluid overflow [5]. The apparatuses of the first group were studied in [6,7], the second group in [5].
The main features of devices with jet injection gas filling are the presence of vertical downward channels with a downward flow or a combination of downward and upward channels both in direct-flow mode and with recirculation of the liquid or gas-liquid phase [8]. In the apparatus of the first group, recirculation occurs due to the airlift effect in the ascending branches of the apparatus and the multiplicity of circulation is determined by the rate of rise of the gas phase. The devices of the second group operate in flow mode, the residence time of the gas-liquid phase and phase contact is determined by the length of the mixing chamber [9]. In the apparatus of the first group, two operating modes are distinguished: the mode of suspension of the gas phase along the height of the vertical downflow channels, the circulation mode through the gas phase.

Taking into account the advantages and disadvantages of existing designs of jet injection apparatuses, the design of the apparatus was proposed. The proposed apparatus provided a high multiplicity of circulation both in the mode 
of suspension of the gas phase along the height of the downflow channels and in the mode of circulation of the gas-liquid flow [3]. One of the structural features of the proposed design of the apparatus is the presence of a pumptype mixing device to provide circulation and jet injection gas saturation.

In [10, 11], hydrodynamics in the vertical channels of jet injection devices with gas-saturated due to a jet of liquid was described. Hydrodynamics in the downflow channels of the apparatus of the second group, as an example of a mine-type apparatus, was investigated in [9]. Therefore, it is relevant to study the size distribution of gas phase bubbles, the gas content and the contact surface of the phases in the apparatus of the proposed design, which allows to determine the modes of its operation.

Thus, the object of research is an apparatus with jet injection gas filling. And the aim of research is determination of the phase contact surface in the downflow channels of the circulating circuit of the apparatus with jet injection gas filling.

\section{Methods of research}

The studies were carried out at the experimental stand shown in Fig. 1, $b$, in a model water-air environment. Model apparatus (1) consists of an upper separation space, a lower overflow and three channels (central - circulation, in which a pump-type mixing device is installed; lateral downflow channels). During research, the apparatus was filled with liquid with a supply of liquid over the overflow of $h_{\text {over }}: 5,10,15,20 \mathrm{~mm}$. The liquid supply over the overflow determines the efficiency of gas accumulation [3]. A laboratory autotransformer (4) measured the voltage across the windings of a DC motor (3). The number of revolutions of the shaft of the mixing device (2) $n$ is 600 , $750,900 \mathrm{rpm}$. The apparatus was filled with a pump (6) from a buffer tank (7) through a flow meter (5).

As a pump-type mixing device, a propeller-type mixer was selected. The level of the clear liquid $H_{l}$ and the height of the gas-liquid layer of the $N_{g l}$ in the reaction tube were measured by differential pressure gauges (8).
The diameter of the bubbles of the gas-liquid layer was photographed in macro mode with a low shutter speed using a Canon camera (9). Further processing of the images was carried out with the employer of a personal computer (10) in the Paint editor. Examples of the results are shown in Fig. 1, $a$. Testing of experimental data and analysis of the results were carried out for the offensive technique.

The surface contact of the phases can be identified for the level [4]:

$$
a=\frac{6 \cdot \bar{\varphi}}{d_{32}}
$$

where $\bar{\varphi}-$ the average gas content along the height of the vertical downward channel; $d_{32}$ - the average surface volumetric or Sauter diameter of the gas phase bubbles.

In [12], the authors analyzed the phase contact surface for ejection jet devices depending on the supplied power. The general equation is obtained:

$$
a=\operatorname{const}\left(\frac{N}{V_{a n}}\right)^{n} \cdot \varphi^{m},
$$

where $N$ - the supplied power; $V_{a n}$ - the volume of the reactor; $n, m$ - the experimentally obtained coefficients.

This approach allows to evaluate the obtained contact surface of the phases depending on the power supplied to the apparatus.

The authors of [13] determined that at a raised power of $2 \ldots 18 \mathrm{~kW} / \mathrm{m}^{3}$, the phase contact surface was $200-1300 \mathrm{~m}^{2} / \mathrm{m}^{3}$. For comparison, in bubblers, the contact surface of the phases is $20 \mathrm{~m}^{2} / \mathrm{m}^{3}$, in bubblers with stirring, $200 \mathrm{~m}^{2} / \mathrm{m}^{3}$.

The average gas content by the height of the reaction tube was determined by the known dependence [5]:

$$
\varphi=\frac{H_{g l}-H_{l}}{H_{g l}}
$$

where $H_{g l}$ - the height of the gas-liquid layer in the vertical channels; $H_{l}$ - the height of the light liquid in the vertical channels.

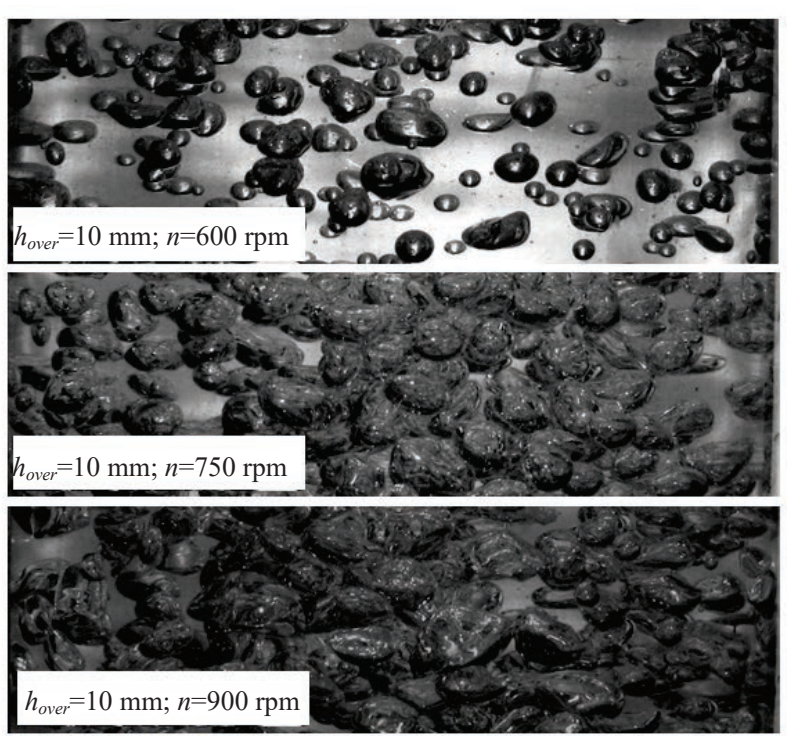

a

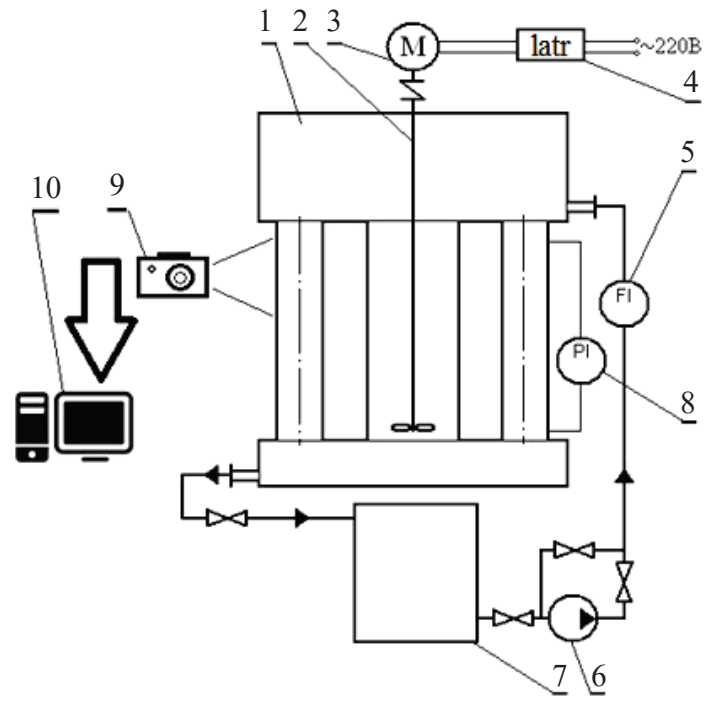

$b$

Fig. 1. The regime with a margin of overhead overflow $h_{\text {over }}=10 \mathrm{~mm}: a$ - characteristic photo of bulbs; $b$ - experimental stand 
The heights of $H_{g l}$ and $H_{l}$ were determined experimentally [5].

The average Sauter diameter in the formula (1) was determined by the formula [14]:

$$
\bar{d}_{32}=\frac{\sum n_{i} \cdot d_{i}^{4}}{\sum n_{i} \cdot d_{i}^{3}},
$$

where $d_{i}$ - the diameter of the bubbles, obtained using the photographic method [5]; $n_{i}-$ the number of bubbles in a given size range.

The average bubble diameter is compared with the maximum stable bubble size [13]:

$$
d_{\max }=C_{1} \frac{\sigma^{0.6}}{\rho_{l}^{0.2}} \cdot\left(\frac{N}{V_{l}}\right)^{-0.4},
$$

where $\sigma-$ the surface tension; $\rho_{l}-$ the density of the liquid; $N$ - the power spent on mixing; $V_{l}$ - the volume of liquid in the apparatus.

The obtained experimental data were processed according to the procedures [15-17]. For each operating mode of the apparatus, depending on the number of revolutions $n$ and the liquid supply over the overflow $h_{\text {over }}$, a dependence of the frequency of occurrence of bubbles of a certain size was constructed. The results obtained made it possible to estimate the distribution law for the size of the bubbles in comparison with the maximum diameter of the bubbles according to formula (5). The nature of the
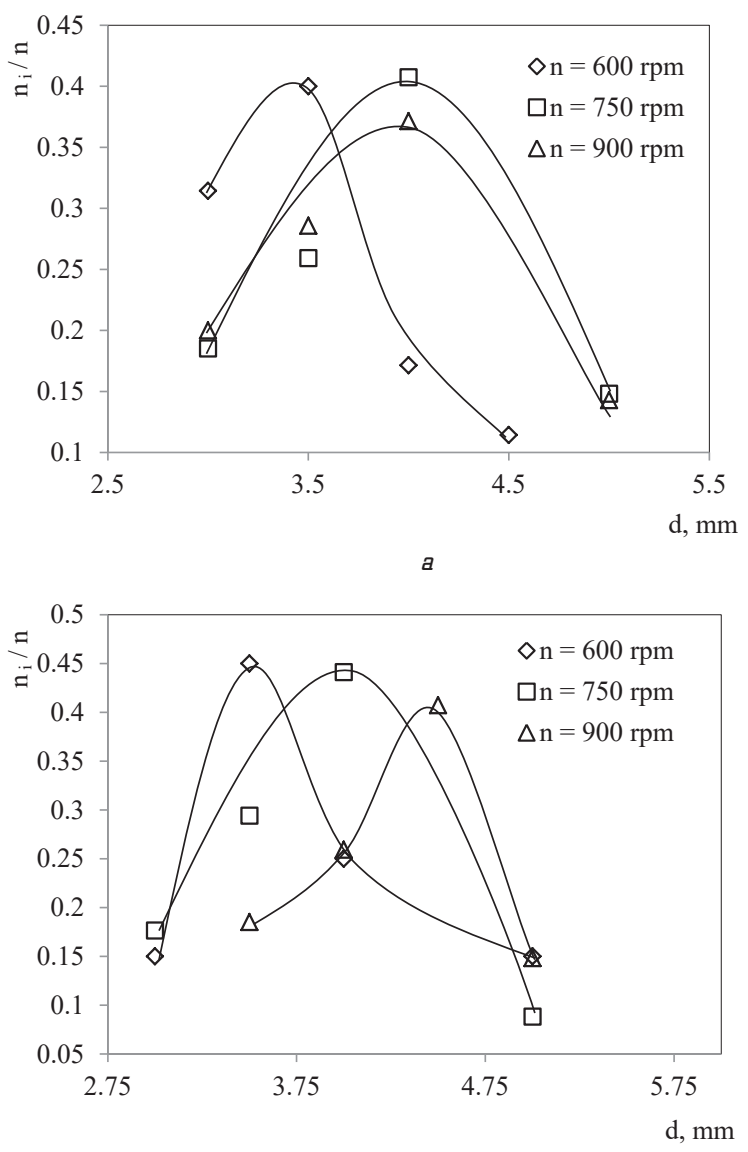

C

Fig. 2. The weight function of the density distribution of bubbles by size with a stationary supply of fluid over the overflow:

$$
a-h_{\text {over }}=20 \mathrm{~mm} ; b-h_{\text {over }}=15 \mathrm{~mm} ; c-h_{\text {over }}=10 \mathrm{~mm} ; d-h_{\text {over }}=5 \mathrm{~mm}
$$

distribution curves made it possible to draw conclusions regarding the completeness of the processes of bubble grinding and bubble coalescence.

\section{Research results and discussion}

At a shaft speed of $600 \mathrm{rpm}$, there is an asymmetry of the bubble distribution curve to the right (Fig. 2, $a-c$ ), most of the bubbles with sizes from $2.5 \mathrm{~mm}$ to $3.5 \mathrm{~mm}$. With a shaft speed of i $900 \mathrm{rpm}$, asymmetry to the left takes place (Fig. 2, $a-c$ ), most of the bubbles with sizes from $3.5 \mathrm{~mm}$ to $4.5 \mathrm{~mm}$. At a speed of $750 \mathrm{rpm}$, the size distribution of bubbles close to normal is about $4 \mathrm{~mm}$ (Fig. 2, $a-c$ ). It can be assumed that the deviation of the histograms from the normal distribution indicates the incompleteness of the process of formation of a gas-liquid layer, which can be facilitated by coalescence or grinding of bubbles.

According to the results of the studies identified:

1. The average diameter of the bubbles (Fig. 3).

The calculation according to formula (4) showed that the diameter of the bubbles increases with an increase in the number of revolutions of the shaft of the mixing device. The mode of suspension of the gas phase took place at shaft rotation numbers from $600 \mathrm{rpm}$ up to $750 \mathrm{rpm}$. With an increase in the number of revolutions, the reaction against the force of bubbling of the bubbles increases and the suspension mode switches to the gas-liquid flow circulation mode. The results obtained for bubble diameter $d_{32}$ are correlated with formula (5).
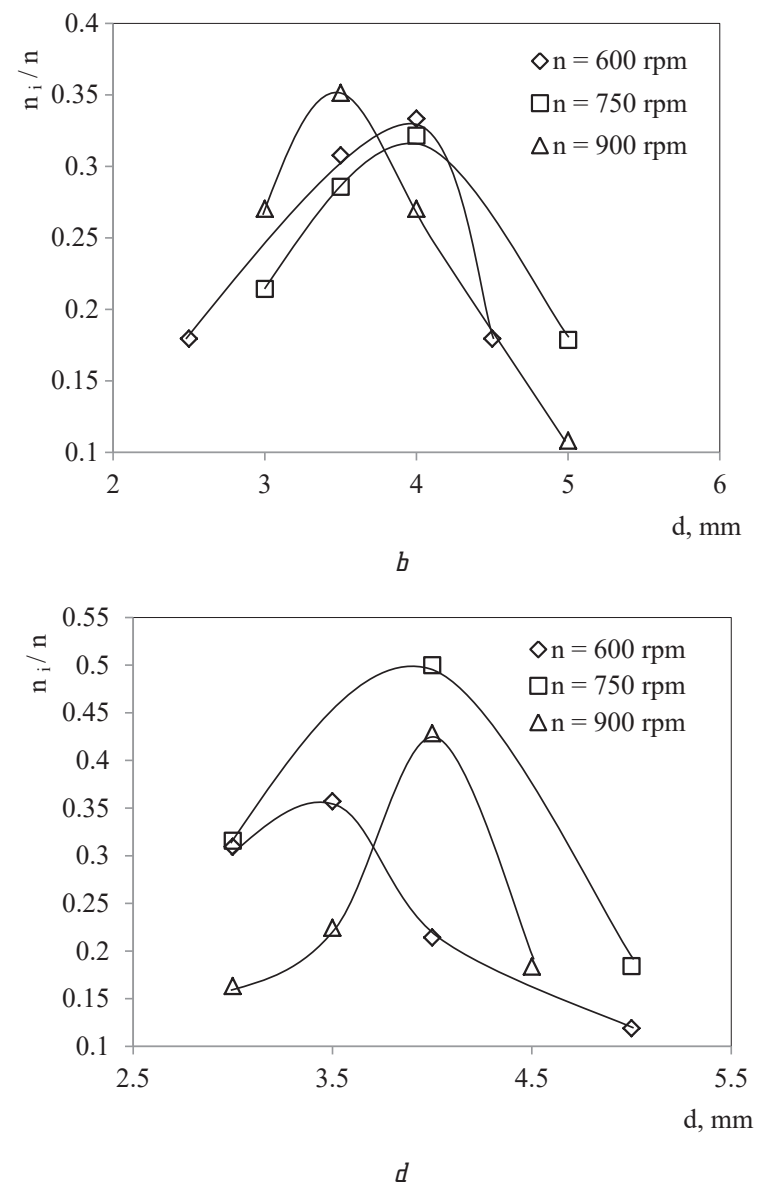


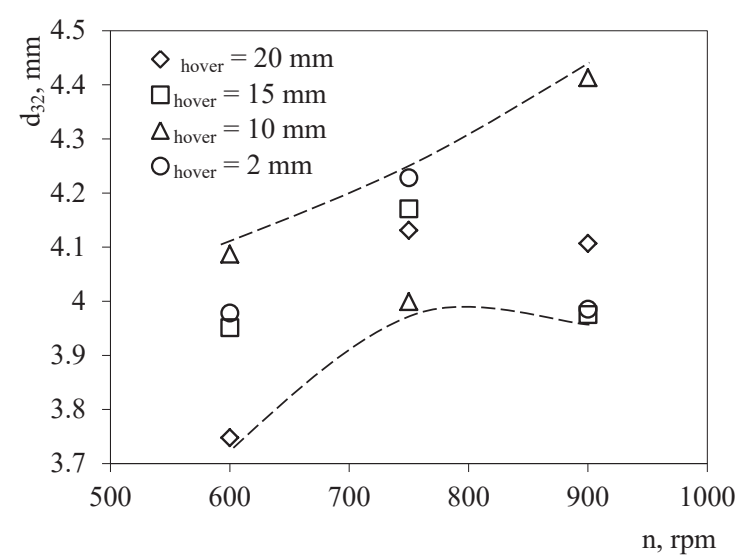

Fig. 3. The average diameter of the bubbles

2. The value of gas content in the downflow channels of the apparatus (Fig. 4, 5).

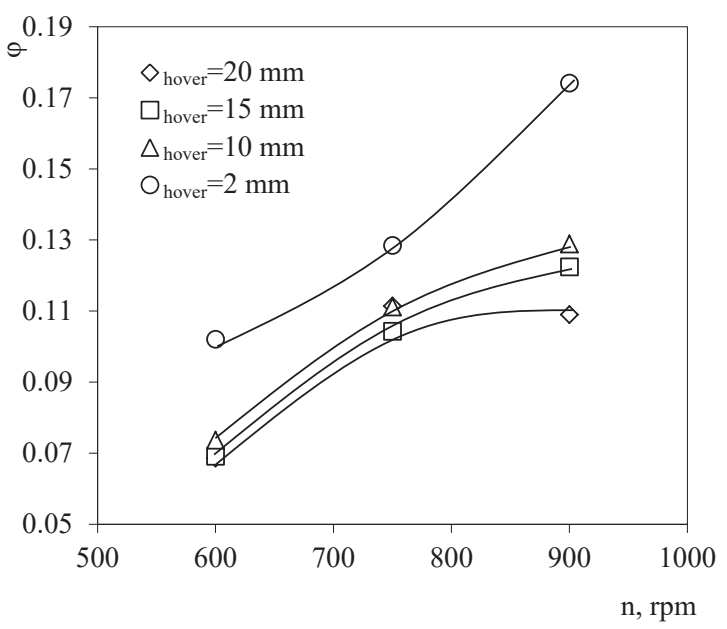

Fig. 4. Gas content in the reaction channels of the apparatus

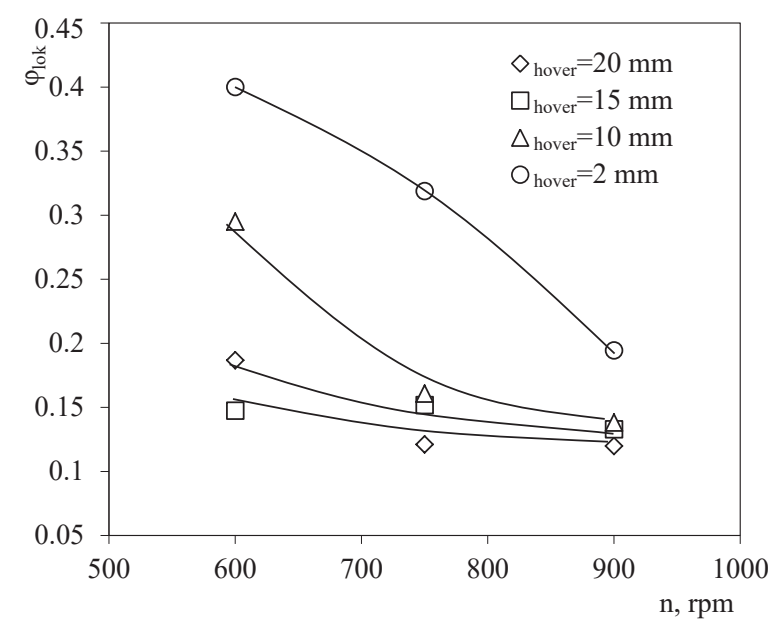

Fig. 5. Local gas content in the reaction channels of the apparatus

The total gas content in the downflow channels (Fig. 4), depending on the liquid supply over the overflow $h_{\text {over }}$ and the number of revolutions of the shaft of the mixing device $n$, varied from $0.07 \ldots 0.10$ to $0.1 \ldots 0.18$, which is typical for gas-liquid apparatus [13]. The local gas content (Fig. 5) ranged from $0.15 \ldots 0.40$ to $0.1 \ldots 0.2$ - the local gas content characterizes the gas content along the height of the gas- liquid layer of the $H_{g l}$. With shaft rotation numbers in the range of $600 \ldots 750 \mathrm{rpm}$, there is a mode of suspension of the gas phase with a tight packing of bubbles, this effect is confirmed by the gas content indicators. With operating modes in the range of $750 \ldots 900 \mathrm{rpm}$, there is a circulation of gas-liquid flow and gas content along the height of the reaction tubes close to the local gas content.

3 . The value of the local and common contact surfaces of the phases (Fig. 6, 7).

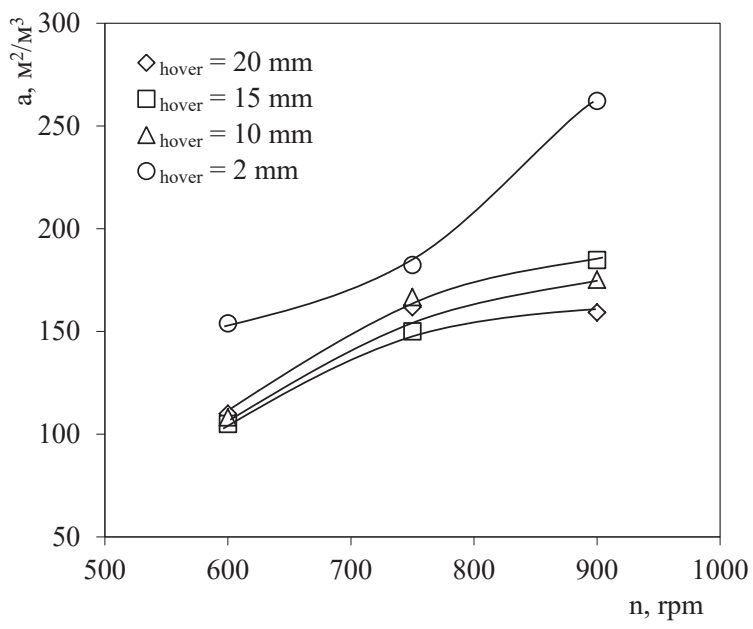

Fig. 6. The contact surface of the phases in the downflow channels of the apparatus

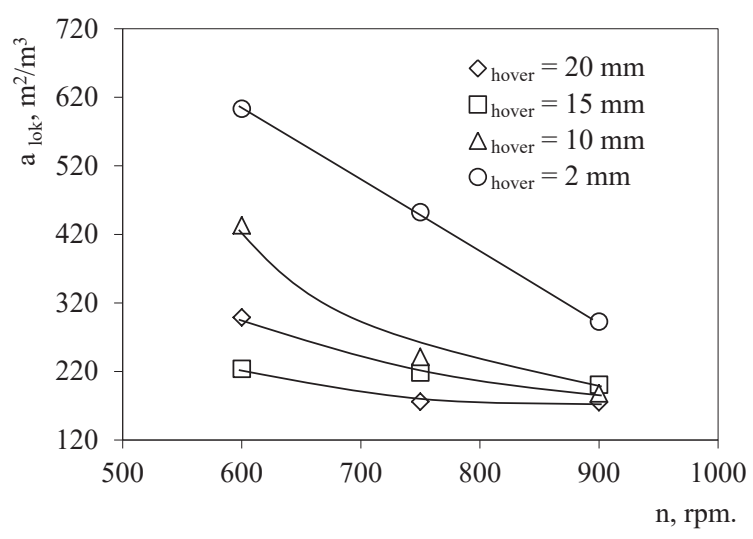

Fig. 7. Local phase contact surface along the height of the gas-liquid layer $H_{g l}$

The total gas content in the downflow channels (Fig. 6) of the apparatus is in the range from 100 to $260 \mathrm{~m}^{2} / \mathrm{m}^{3}$ of the reaction volume and is typical for most gas-liquid bubblers. The local gas content along the height of the gas-liquid layer characterizes the packing density of the bubbles, in the initial mode when the gas phase is suspended, the height of the gas-liquid layer is about $1 / 3$ of the height of the reaction tube with a downstream flow. At speeds of about $750 \mathrm{rpm}$, the height of the gas-liquid layer is about $2 / 3$, a further increase in the number of revolutions leads to a regime of circulation of the gasliquid flow, and the value of the local and common contact surfaces of the phases approximately become equal.

\section{Conclusions}

The obtained research results show that the size of the bubbles, gas content, and phase contact surface are charac- 
teristic of most bubblers. The main novelty is the ability to control operation modes due to the suspension of the gas phase along the height of the downflow channels. As a result of the studies, the gas content is established in the mode of suspension of the gas phase $\varphi=0.2-0.4$ and the specific contact surface of the phases $a=320-620 \mathrm{~m}^{2} / \mathrm{m}^{3}$. Taking into account that the residence time of the gas phase in the volume of the apparatus is longer than in bubblers and airlift devices, it is possible to assume that the degree of response of the gas phase should be longer. The obtained research results can be used in the study of mass transfer in circulating apparatuses with jet injection gas filling in the mode of suspension of the gas phase. These devices and operating modes are promising for carrying out processes such as chlorination of water with gaseous chlorine and the production of ammonia water.

\section{References}

1. Iablokova, M. A., Sokolov, V. N., Sugak, A. V. (1988). Gidrodinamika i massoperenos pri struinom aerirovanii zhidkostei. Teoreticheskie osnovy khimicheskoi tekhnologi, 6, 734-739.

2. Ved, V. V., Iushko, V. L., Pticin, S. G., Iariz, V. A. (2008) Optimizaciia apparaturnogo oformleniia stadii ammonizacii $\mathrm{v}$ proizvodstve kompleksnykh mineralnykh udobrenii. Voprosy khimii i khimicheskoi tekhnologi, 1, 159-163.

3. Ved, V. V. (2013). Struktura gazoridinnogo potoku ta rezhimi roboti cirkuliaciinogo aparatu zi strumenevi-inzhekciinim gazonapovnenniam. Voprosy khimii i khimicheskoi tekhnologi, 3, 214-219.

4. Ramm, V. M. (1976). Absorbcii gazov. Moscow: Khimiia, 656.

5. Sokolov, V. N., Domanskii, I. V. (1976). Gazozhidkostnye reaktory. Leningrad: Mashinostroenie, 216.

6. Ibragimov, T. S., Chebotar, A. V., Novoselov, A. G. (2012). Proizvodstvo etilovogo spirta v kozhukhotrubnom struinoinzhekcionnom apparate po nizkotemperaturnoi skheme. Tekhnika i tekhnologiia pischevykh proizvodstv, 1 (24), 112-115.

7. Iablokova, M. A., Ivanova, O. M., Petrov, S. I. (2010). Utochnennaia matematicheskaia model processa ozonirovaniia vody v inzhekcionno-struinykh aparatakh. Izvestiia Sankt-Peterburgskogo gosudarstvennogo tekhnologicheskogo instituta, 7, 88-93.

8. Sivenkov, A. V., Novoselov, A. G. (2008). Gidrodinamicheskii raschet dvizheniia dvukhfaznykh potokov v vertikalnykh trubakh kozhukhotrubnogo struino-inzhekcionnogo apparata (KSIA) protochnogo tipa s dopolnitelnym soplom nad slivom (Chast 1). Izvestiia SPbGUNiPT, 2, 6-10.

9. Sokolov, V. N., Iablokova, M. A. (1988). Apparatura mikrobiologicheskoi promyshlennosti. Leningrad: Mashinostroenie. Leningr. otd-nie, 278.

10. Kashinskii, O. N., Randin, V. V. (1999). Opusknoe gazozhidkostnoe puzyrkovoe techenie v vertikalnoi trube. Teplofizika i aeromekhanika, 6 (2), 235-246.
11. Terekhov, V. I., Pakhomov, M. A. (2008). The effect of bubbles on the structure of flow and the friction in downward turbulent gas-liquid flow. High Temperature, 46 (6), 924-930. doi: http:// doi.org/10.1134/s0018151x08060163

12. Shalygin, E. V., Leontev, V. K., Abramova, T. E. (2009). Raschet diametra puzyria i parametra effektivnosti dlia gazozhidkostnykh reaktorov s ezhekcionnym dispergirovaniem. Izvestiia oysshikh uchebnykh zavedenii. Seriia: Khimiia i khimicheskaia tekhnologiia, 52 (7), 118-121.

13. Mukhametzianova, A. G., Diakonov, G. S., Kulmenteva, E. I., Etrovicheva, E. A. (2004). Processy perenosa i khimicheskogo prevrascheniia pri turbulentnom smeshenii v kanalakh s iskusstvennoi turbulizaciei sredy. Vestnik Kazanskogo tekhnologicheskogo universiteta, 1, 164-171.

14. Majumder, S. K., Kundu, G., Mukherjee, D. (2006). Bubble size distribution and gas-liquid interfacial area in a modified downflow bubble column. Chemical Engineering Journal, 122 (1-2), 1-10. doi: http://doi.org/10.1016/j.cej.2006.04.007

15. Mandal, A. (2010). Characterization of gas-liquid parameters in a down-flow jet loop bubble column. Brazilian Journal of Chemical Engineering, 27 (2), 253-264. doi: http://doi.org/10.1590/ s0104-66322010000200004

16. Ohkawa, A., Kawai, Y., Kusabiraki, D., Sakai, N., Endoh, K. (1987). Bubble size, interfacial area and volumetric liquid-phase mass transfer coefficient in downflow bubble columns with gas entrainment by a liquid jet. Journal of Chemical Engineering of Japan, 20 (1), 99-101. doi: http://doi.org/10.1252/jcej.20.99

17. Yamagiwa, K., Kusabiraki, D., Ohkawa, A. (1990). Gas holdup and gas entrainment rate in downflow bubble column with gas entrainment by a liquid jet operating at high liquid throughput. Journal of Chemical Engineering of Japan, 23 (3), 343-348. doi: http://doi.org/10.1252/jcej.23.343

Ved Viktor, Senior Lecturer, Department of Equipment of Chemical Plants, Ukrainian State University of Chemical Technology, Dnipro, Ukraine, e-mail: 251277ved@gmail.com, ORCID: http://orcid.org/ 0000-0002-2391-6463

Nikolsky Valeriy, Doctor of Technical Sciences, Professor, Department of Energetic, Ukrainian State University of Chemical Technology, Dnipro, Ukraine, e-mail: vnikols1@gmail.com, ORCID: http://orcid.org/ 0000-0001-6069-169X

Okhtina Oxsana, PhD, Associate Professor, Department of Organic Substances and Pharmaceuticals, Ukrainian State University of Chemical Technology, Dnipro, Ukraine, e-mail: oksanaohtina@gmail.com, ORCID: http://orcid.org/0000-0001-5375-5608

Kiselev Vadym, PhD, Associate Professor, Department of Organic Substances and Pharmaceuticals, Ukrainian State University of Chemical Technology, Dnipro, Ukraine, e-mail: vadvitkis@gmail.com, ORCID: http://orcid.org/0000-0002-5623-328X 